\title{
CAMA
}

Centre for Applied Macroeconomic Analysis

\section{Dealing with time-inconsistency: Inflation targeting vs. exchange rate targeting}

\section{CAMA Working Paper 54/2017 August 2017}

\author{
J. Scott Davis \\ Federal Reserve Bank of Dallas
}

\section{Ippei Fujiwara}

Keio University

Crawford School of Public Policy, ANU and

Centre for Applied Macroeconomic Analysis, ANU

\author{
Jiao Wang \\ University of Melbourne
}

\section{Abstract}

Abandoning an objective function with multiple targets and adopting single mandate can be an effective way for a central bank to overcome the classic time-inconsistency problem. We show that the choice of a particular single mandate depends on an economy's level of trade openness and the credibility of the central bank. We begin with reduced form empirical results which show that as central banks become less credible they are more likely to adopt a pegged exchange rate, and crucially, the tendency to peg depends on trade openness. Then in a model where the central bank displays "loose commitment" we show that as central bank credibility falls, they are more likely to adopt either an inflation target or a pegged exchange rate. A relatively closed economy would adopt an inflation target to overcome the time-inconsistency problem, but a highly open economy would prefer an exchange rate peg. 


\title{
Keywords
}

Time-inconsistency, Commitment, Inflation target, Exchange rate peg, Tie-one's-hands

\author{
JEL Classification
}

E50, E30, F40

\section{Address for correspondence:}

(E) cama.admin@anu.edu.au

\section{ISSN 2206-0332}

The Centre for Applied Macroeconomic Analysis in the Crawford School of Public Policy has been established to build strong links between professional macroeconomists. It provides a forum for quality macroeconomic research and discussion of policy issues between academia, government and the private sector.

The Crawford School of Public Policy is the Australian National University's public policy school, serving and influencing Australia, Asia and the Pacific through advanced policy research, graduate and executive education, and policy impact. 


\title{
Dealing with time-inconsistency: Inflation targeting vs. exchange rate targeting*
}

\author{
J. Scott Davis ${ }^{\dagger}$
}

\author{
Ippei Fujiwara
}

Jiao Wang§

\author{
August 2017
}

\begin{abstract}
Abandoning an objective function with multiple targets and adopting single mandate can be an effective way for a central bank to overcome the classic time-inconsistency problem. We show that the choice of a particular single mandate depends on an economy's level of trade openness and the credibility of the central bank. We begin with reduced form empirical results which show that as central banks become less credible they are more likely to adopt a pegged exchange rate, and crucially, the tendency to peg depends on trade openness. Then in a model where the central bank displays "loose commitment" we show that as central bank credibility falls, they are more likely to adopt either an inflation target or a pegged exchange rate. A relatively closed economy would adopt an inflation target to overcome the time-inconsistency problem, but a highly open economy would prefer an exchange rate peg.
\end{abstract}

JEL Codes: E50; E30; F40

Keywords: Time-inconsistency; Commitment; Inflation target; Exchange rate peg; Tie-one's-hands

*We thank the editor, Kenneth West, and two anonymous referees for many insightful comments and suggestions. We also have benefited from discussions with Mario Crucini, Richard Dennis, Jinill Kim, Marianio Kulish, James Hansen, Sylvain Leduc, Zheng Liu, Ricardo Nunes, Frank Smets, Mark Spiegel and seminar and conference participants at the Federal Reserve Banks of Dallas, Boston, and San Francisco, Vanderbilt University, the central bank modelling workshop at the Reserve Bank of New Zealand, the 2015 Melbourne Macroeconomic Policy Meetings and the 2017 SED meetings in Edinburgh. The views presented here are those of the authors and do not necessarily represent the views of the Federal Reserve Bank of Dallas or the Federal Reserve System. Fujiwara gratefully acknowledges financial support from JSPS KAKENHI Grant-in-Aid for Scientific Research (A) Grant Number 15H01939. Wang is grateful for financial support from Australian Research Council Discovery Project 160102654.

${ }^{\dagger}$ Federal Reserve Bank of Dallas. email: scott.davis@dal.frb.org

$¥$ Keio University and Australian National University. email: ippei.fujiwara@keio.jp

$\S$ University of Melbourne. email: jiao.wang@unimelb.edu.au 


\section{Introduction}

The work of Kydland and Prescott (1977) and Barro and Gordon (1983) highlight the importance of time consistency in policy making. Countries with a weak institutional framework may lack the ability to commit to a future course of monetary policy. This problem arises when a central bank tries to maximize (or minimize) an objective function with multiple terms. There is the motivation to use policy to make temporary gains in some variables (like output) by taking advantage of the fact that expectations about other variables (like inflation) are fixed in the short run. In this case optimal monetary policy may be to switch from a central bank objective where the central bank tries to maximize social welfare and instead adopt a simpler single mandate.

This is the motivation behind the famous conservative central banker in Rogoff (1985). As discussed by Bernanke, Laubach, and Mishkin (2001), an inflation targeting single mandate can help overcome the time-inconsistency problem and an inflation target can help anchor inflation expectations. Ever since the adoption of an inflation targeting single mandate by the Reserve Bank of New Zealand in 1989, there have been a number of empirical studies that have shown that the adoption of an inflation targeting single mandate leads to a significant reduction in inflation and inflation expectations in both developed and developing countries. ${ }^{1}$

Historically the adoption of a nominal exchange rate targeting single mandate has been the preferred solution to the time-inconsistency problem in many countries. ${ }^{2}$ Bordo and Kydland (1995) discuss this practice of pegging one's currency to gain credibility in terms of the pre-World War 1 gold standard. Bordo (2003) discusses how the development of institutions like strong, independent central banks has been an important precursor to the widespread adoption of floating currencies by many developed countries since the end of the Bretton Woods system. Giavazzi and Pagano (1988) and Giavazzi and Giovannini (1989) discuss how "tieing one's hands" by pegging the currency to the German Deutsche Mark was an important motivation behind the European Exchange Rate Mechanism, the precursor to the euro. Similarly, Calderón and Schmidt-Hebbel (2003) discuss the practice of pegging to gain credibility in many Latin American countries, and Mishkin and Calvo (2003) and

\footnotetext{
${ }^{1}$ Gürkaynak, Levin, and Swanson (2006), Mishkin and Schmidt-Hebbel (2007), Walsh (2007), Gürkaynak, Marder, Levin, and Swanson (2007), Benati (2008), Gonçalves and Salles (2008), Crowe (2010), Beechey, Johannsen, and Levin (2011), Mehrotra and Yetman (2014), Davis (2014) all argue that the adoption of inflation targeting has led to lower and more stable inflation and inflation expectations. However, Ball and Sheridan (2005), Brito and Bystedt (2010), Lin and Ye (2007, 2009) argue that these effects are due to common time components or selection bias and reversion to the mean (this would occur when inflation is mean reverting and countries adopt inflation targeting only when inflation is high).

${ }^{2}$ Recently, following the adoption of an inflation targeting mandate by the Reserve Bank of New Zealand in 1989, inflation targeting has become the single mandate of choice in many developed and emerging market economies.
} 
Husain, Mody, and Rogoff (2005) discuss this practice in many developing and emerging market economies.

When modeling why countries may have a "fear of floating", Calvo and Reinhart (2002) specifically model how a central bank that lacks the ability to commit will find it optimal to peg their exchange rate. Herrendorf $(1997,1999)$ discusses adopting a currency peg as an effective communication device by a central bank that practices discretionary policy and shows how pegging the currency has reputational benefits and may be a necessary precursor for successfully floating the currency under a credible central bank. ${ }^{3}$

It is well known and has been extensively modelled how adopting one of these two single mandates, inflation targeting or nominal exchange rate targeting, is a possible solution to the time-inconsistency problem. ${ }^{4}$ This paper will show that the particular single mandate chosen depends on trade openness and the credibility of the central bank. In order to improve welfare given low central bank credibility, a highly open economy may find it optimal to adopt an external target, like an exchange rate targeting mandate, while a relatively closed economy will find it optimal to adopt a domestic target, like the inflation rate. ${ }^{5}$

We begin with the results from a reduced form empirical exercise which show that countries with low levels of central bank credibility or independence are more likely to adopt a fixed exchange rate regime. Furthermore, these empirical results show that this tendency to peg the exchange rate to overcome a lack of central bank credibility depends on trade openness. Highly open economies are likely to adopt a pegged exchange rate to overcome a lack of central bank credibility, but relatively closed economies are unlikely to adopt an

\footnotetext{
${ }^{3}$ In related empirical studies, Levy Yeyati, Sturzenegger, and Reggio (2010) show that the strength of political institutions is one key factor in explaining exchange rate regime choice. Similarly, Hakura (2005) finds that exchange rate flexibility in emerging market countries has increased over the past decade, and argues that this "learning to float" appears to have involved a strengthening of monetary and financial policy frameworks in many countries. Ghosh (2014) finds that trade openness leads to the tendency to adopt a fixed currency in many emerging markets.

This is related to the seminal work in Romer (1993) which shows that the net benefits of an unexpected monetary expansion decrease as trade openness increases. Therefore central banks in highly open economies are much less likely to pursue such actions when engaging in discretionary monetary policy, and as a result, the inflation bias associated with discretionary policy is lower for a highly open economy.

${ }^{4}$ Models of the Barro-Gordon type showing the advantages of pegging the currency when the central bank lacks the ability to commit are detailed in Obstfeld and Rogoff (1996). One contribution of this paper is to model the gains from pegging in the linear-quadratic framework from Woodford (2003).

${ }^{5}$ Here we assume that international capital markets are open, so as implied by the famous MundellFlemming trilemma (see e.g. Mundell (1963) and Fleming (1962)) the adoption of nominal exchange rate targeting entails giving up an independent monetary policy. If one were to restrict capital market openness, sterilized foreign exchange intervention would be possible, where the central bank could manage the exchange rate using sterilized foreign exchange intervention and still maintain an independent monetary policy. Empirically Ghosh, Ostry, and Chamon (2016) show that the combination of inflation targeting with exchange rate targeting through sterilized foreign exchange intervention can result in a major improvement in the volatility of certain observable variables.
} 
exchange rate peg, even at low levels of central bank credibility.

Using a model of optimal monetary policy in a small open economy, we show through impulse response and welfare calculations that when the trade share is low, an inflation targeting mandate results in higher social welfare than a nominal exchange rate targeting mandate. But as the import share increases, the relative ordering switches and the nominal exchange rate target outperforms inflation targeting (both domestic producer price inflation targeting and consumer price inflation targeting).

However, in all these cases, welfare maximizing policy under commitment is better than (or at least as good as) any simple rule monetary regime. ${ }^{6}$ Therefore we then model how a central bank will find it optimal to adopt an inflation targeting or an exchange rate targeting mandate as their credibility falls. Using the loose commitment framework of Schaumburg and Tambalotti (2007) and Debortoli and Nunes (2010) we assume that central bank credibility lies on a continuum between perfect commitment and perfect discretion. We solve for the optimal policy equilibrium for all values of the credibility along the continuum from commitment to discretion. As credibility falls the outcome from welfare maximizing policy gets progressively worse. We explore how the central bank could improve total social welfare by adopting a different objective function that places greater weight on inflation stability or on nominal exchange rate stability. ${ }^{7}$ We solve numerically for the optimal weight on inflation or nominal exchange rate stability in the central bank's objective function and show that it is a function of the commitment probability. In that way we can analyze the link between the central bank's credibility and the optimal degree of inflation or exchange rate targeting.

When the economy is relatively closed, credibility has to be very low before the central bank will find it optimal to switch from welfare maximizing policy to an exchange rate targeting single mandate, and at some low levels of trade openness, purely discretionary monetary policy outperforms an exchange rate target. However, for a country that is very open to trade, the central bank will quickly abandon welfare maximizing policy and instead adopt exchange rate targeting at even a relatively high level of credibility. ${ }^{8}$

\footnotetext{
${ }^{6}$ Throughout this paper we refer to "welfare maximizing policy" as a policy where the central bank maximizes an objective function which is the second-order approximation of social welfare. The derivation of this objective function in a small open economy under local currency pricing is an important technical contribution of this paper.

${ }^{7}$ In that way, this model is a small open economy version of the Rogoff (1985) conservative central banker in a linear quadratic framework.

${ }^{8}$ Devereux and Engel (2003) discuss the optimality of a fixed exchange rate regime, but in these models, the central bank can commit. The prevalence of local currency pricing and the violation of the law of one price either diminishes the expenditure switching benefit of a floating currency or imposes a cost in terms of increased price dispersion.

Similarly, in a model where the central bank can commit, Kamenik and Kumhof (2014) compare the welfare outcomes of a fixed exchange rate regime to a floating regime that follows a Taylor-type feedback rule with a medium term inflation target.
} 
The rest of this paper is organized as follows. Some reduced form empirical results that show the link between central bank credibility, trade openness, and the tendency to peg the exchange rate are presented in section 2. A New Keynesian model of optimal monetary policy in a small open economy is presented in section 3. The results from this model are presented in section 4. Through impulse responses and the numerical calculation of welfare costs we show how the relative costs and benefits of nominal exchange rate targeting depends on an economy's level of trade openness and central bank credibility. Finally, section 5 concludes.

\section{Empirical}

Central banks that lack the ability to commit to future policy actions can improve their monetary policy outcome by choosing to peg the nominal exchange rate to that of a more credible partner. In this section we show empirical evidence that as a central bank gains credibility, it tends to loosen any currency pegs and adopt a floating exchange rate. Furthermore, we show that the empirical link between central bank credibility and exchange rate flexibility depends on a country's level of trade openness.

\subsection{Empirical model, variables, and data}

We will estimate a panel data model with an index of exchange rate flexibility as the dependent variable and a proxy for central bank credibility as the independent variable. In this panel we use annual data from 96 countries over 13 years, from 1998-2010. The full list of countries can be found in section 2 of the appendix.

The dependent variable in this empirical exercise is an index of whether a country has a fixed or floating exchange rate from Ilzetzki, Reinhart, and Rogoff (2008). This index varies from (1) - "no separate legal tender" to (13) - "freely floating" and in between covers varying degrees of exchange rate pegs. The exact definitions for each of the 13 index values are found in the appendix.

As a proxy for central bank credibility we use the index of central bank independence from Dincer and Eichengreen (2013). Central bank independence has been used as a proxy for central bank credibility and institutional quality from as early as Cukierman (1992) and Alesina and Summers (1993). Blinder (2000) reports that a vast majority of both central bank governors and academic economists cite central bank independence as one of the most important factors behind central bank credibility.

We also include a measure of trade openness (the sum of imports and exports divided by GDP) as another independent variable and in one regression specification we estimate the 
interaction between central bank independence and trade openness.

As control variables in this panel data regression we include the CPI inflation rate and the GDP growth rate in the previous year. We also include country fixed effects in this panel data regression.

\subsection{Empirical Results}

The results from this panel data regression of exchange rate flexibility on central bank independence are presented in table 1 . The first two columns of the table present the results from the panel that includes all 96 countries, and the last two columns in the table present the results for the subsample of 75 developing and emerging market countries.

The coefficient of central bank independence is positive and significant, indicating that when central bank independence improves in year $t-1$, holding all else equal, the index of exchange rate flexibility will shift towards floating in year $t$.

In the second column in the table we include an interaction term between central bank credibility and the level of trade openness. The coefficient on this interaction term is positive and significant, indicating that the link between central bank credibility and the desire to peg the nominal exchange rate is a function of a country's level of trade openness. For a relatively closed economy there is not a significant relationship between credibility and the desire to peg the exchange rate. For a highly open economy, the link between credibility and the desire to peg the exchange rate is strong.

The lagged values of the CPI inflation rate or the GDP growth rate do not have an effect on the degree of exchange rate flexibility. The last two columns in the table show that these same results hold not just for the full panel of 96 countries but also for the sub-panel of 75 developing and emerging market countries.

\section{Model}

In the model there are two countries, home and foreign. The home country is of size $n$ and the foreign country is of size $1-n$, and we consider a case of the small open economy where $n \rightarrow 0$. The home economy is populated by a representative household and a continuum of firms. Firms employ labor to produce a tradable consumption good and set prices according to a Calvo style price setting framework. There is a central bank which sets the nominal interest rate. We model outcomes under a few assumptions about the behavior of the central bank. In some cases we assume that the central bank sets policy to maximize the secondorder approximation of household welfare. In others we assume that the central bank follows 
either a partial or full inflation or exchange rate target.

\subsection{Households}

In the small open home economy, the representative household chooses consumption, $C_{t}$, and labor effort, $H_{t}$, to maximize expected lifetime utility given by:

$$
\max E_{0} \sum_{t=0}^{\infty} \beta^{t}\left[\frac{C_{t}^{1-\rho}}{1-\rho}-\frac{H_{t}^{1+\eta}}{1+\eta}\right]
$$

where $\beta$ is the household's discount factor, $\rho$ is the inverse of the intertemporal substitution elasticity, and $\eta$ is the inverse of the Frisch labor supply elasticity.

The aggregate consumption good is simply the aggregation of domestic and imported goods from individual firms aggregated in the CES function:

$$
C_{t}=\left[\begin{array}{c}
v^{\frac{1}{\theta}}\left[\left(\left(\frac{1}{n}\right)^{\frac{1}{\sigma}} \int_{0}^{n} C_{t}^{H}(i)^{\frac{\sigma-1}{\sigma}} d i\right)^{\frac{\sigma}{\sigma-1}}\right]^{\frac{\theta-1}{\theta}} \\
+(1-v)^{\frac{1}{\theta}}\left[\left(\left(\frac{1}{1-n}\right)^{\frac{1}{\sigma}} \int_{n}^{1} C_{t}^{F}(j)^{\frac{\sigma-1}{\sigma}} d j\right)^{\frac{\sigma}{\sigma-1}}\right]^{\frac{\theta-1}{\theta}}
\end{array}\right]^{\frac{\theta}{\theta-1}}
$$

where $C_{t}^{H}(i)$ is the quantity of goods sold to the home market by home country firm $i \in[0 \quad n]$ and $C_{t}^{F}(j)$ is the quantity imported into the home market and sold by foreign country firm $j \in(n 1]$. $\theta$ is the elasticity of substitution between home and foreign goods, and $\sigma$ is the elasticity of substitution between goods from different firms within the same country.

From the aggregator function in (2), the demand for either the home consumption good from firm $i$ or the foreign consumption good from firm $j$ are given by:

$$
\begin{aligned}
C_{t}^{H}(i) & =v\left(\frac{P_{t}^{H d}(i)}{P_{t}^{H d}}\right)^{-\sigma}\left(\frac{P_{t}^{H d}}{P_{t}}\right)^{-\theta} C_{t} \\
C_{t}^{F}(j) & =(1-v)\left(\frac{P_{t}^{F x}(j)}{P_{t}^{F x}}\right)^{-\sigma}\left(\frac{P_{t}^{F x}}{P_{t}}\right)^{-\theta} C_{t}
\end{aligned}
$$

and the corresponding demand functions in the foreign economy are given by:

$$
\begin{aligned}
C_{t}^{F *}(j) & =v^{*}\left(\frac{P_{t}^{F d}(j)}{P_{t}^{F d}}\right)^{-\sigma}\left(\frac{P_{t}^{F d}}{P_{t}^{*}}\right)^{-\theta} C_{t}^{*} \\
C_{t}^{H *}(i) & =\left(1-v^{*}\right)\left(\frac{P_{t}^{H x}(i)}{P_{t}^{H x}}\right)^{-\sigma}\left(\frac{P_{t}^{H x}}{P_{t}^{*}}\right)^{-\theta} C_{t}^{*}
\end{aligned}
$$

where $P_{t}^{H d}(i)$ is the price set by firm $i$ for the domestic market (in home currency), $P_{t}^{H x}(i)$ 
is the price of the home good from firm $i$ in the foreign market (in foreign currency), $P_{t}^{F d}(j)$ is the price set by foreign firm $j$ for sales in the foreign market (in the foreign currency), and $P_{t}^{F x}(j)$ is the price set by foreign firm $j$ for sales in the home market (in home currency). In the main text of this paper, we consider the model with local currency pricing, and thus the home country firm $i$ can set separate prices $P_{t}^{H d}(i)$ and $P_{t}^{H x}(i)$ for the local and foreign markets and the foreign country firm $j$ can set separate prices $P_{t}^{F d}(j)$ and $P_{t}^{F x}(j)$. The share of imported goods in the home consumption basket is given by $1-v$ and the share of imported goods in the foreign consumption basket is given by $1-v^{*}$.

Given the lack of full exchange rate pass through observed in the data (see e.g. Campa and Goldberg (2005)), the assumption of local currency pricing is a more empirically relevant starting point. In the appendix we will also consider the case of producer currency pricing. In this the law of one price holds at the level of the individual good and thus exchange rate pass through is complete: $P_{t}^{H d}(i)=S_{t} P_{t}^{H x}(i)$ and $P_{t}^{F d}(j)=\frac{P_{t}^{F x}(j)}{S_{t}}$, where $S_{t}$ is the nominal exchange rate in units of the domestic currency per units of the foreign currency. Thus the various price indices are given by:

$$
\begin{aligned}
P_{t}^{H d} & =\left(\frac{1}{n} \int_{0}^{n} P_{t}^{H d}(i)^{1-\sigma} d i\right)^{\frac{1}{1-\sigma}} \text { and } P_{t}^{H x}=\left(\frac{1}{n} \int_{0}^{n} P_{t}^{H x}(i)^{1-\sigma} d i\right)^{\frac{1}{1-\sigma}} \\
P_{t}^{F d} & =\left(\frac{1}{1-n} \int_{n}^{1} P_{t}^{F d}(j)^{1-\sigma} d j\right)^{\frac{1}{1-\sigma}} \text { and } P_{t}^{F x}=\left(\frac{1}{1-n} \int_{n}^{1} P_{t}^{F x}(j)^{1-\sigma} d j\right)^{\frac{1}{1-\sigma}} \\
P_{t} & =\left[v\left(P_{t}^{H d}\right)^{1-\theta}+(1-v)\left(P_{t}^{F x}\right)^{1-\theta}\right]^{\frac{1}{1-\theta}} \text { and } P_{t}^{*}=\left[v^{*}\left(P_{t}^{F d}\right)^{1-\theta}+\left(1-v^{*}\right)\left(P_{t}^{H x}\right)^{1-\theta}\right]^{\frac{1}{1-\theta}}
\end{aligned}
$$

The home country domestic producer price inflation rate is given by $\pi_{t}^{H d}=\frac{P_{t}^{H d}}{P_{t-1}^{H d}}-1$, home country import price inflation is given by $\pi_{t}^{H m}=\frac{P_{t}^{F x}}{P_{t-1}^{F x}}-1$, and foreign country consumer price inflation is given by $\pi_{t}^{*}=\frac{P_{t}^{*}}{P_{t-1}^{*}}-1$. From the last identity we can express home country consumer price inflation $\pi_{t}^{C}=\frac{P_{t}}{P_{t-1}}-1$, as a weighted average of the inflation rate of home and foreign produced goods and appreciation in the nominal exchange rate:

$$
\pi_{t}^{C}=v \pi_{t}^{H d}+(1-v) \pi_{t}^{H m}
$$

where $1-v=(1-n) \lambda$, and in the limit as $n \rightarrow 0, v=1-\lambda$, where $\lambda$ is the steady-state import share. And thus consumer price inflation in the small open economy is simply a trade weighted average of domestic producer inflation and imported inflation. Notice as well that when the home economy is a small open economy, foreign consumer price inflation is equal to foreign producer price inflation. 
In addition, the household's labor supply decision can be expressed as:

$$
H_{t}^{\eta}=\frac{W_{t}}{P_{t}} C_{t}^{-\rho}
$$

\subsubsection{Asset Market Structure}

We assume that asset markets are complete both domestically and internationally. Thus agents have access to a complete set of state-contingent securities. This implies that the intertemporal marginal rate of substitution is equalized across countries:

$$
\left(\frac{C_{t}}{C_{t+1}}\right)^{-\rho} \pi_{t+1}^{C}=\frac{S_{t+1}}{S_{t}}\left(\frac{C_{t}^{*}}{C_{t+1}^{*}}\right)^{-\rho} \pi_{t+1}^{*}
$$

Using (5) and the definition of the real exchange rate, $Q_{t}=\frac{S_{t} P_{t}^{*}}{P_{t}}$, after assuming that countries have the same initial wealth levels it follows that:

$$
Q_{t}=\left(\frac{C_{t}^{*}}{C_{t}}\right)^{-\rho}
$$

Thus under complete asset markets, the price of the foreign consumption good relative to the home consumption good, $Q_{t}$, is equal to the marginal utility of foreign consumption divided by the marginal utility of home consumption.

\section{$3.2 \quad$ Firms}

Home country firm $i \in\left[\begin{array}{ll}0 & n\end{array}\right]$ produces output for the domestic market and for exports. The firm's total output is simply the sum of the two, $Y_{t}(i)=C_{t}^{H}(i)+\frac{1-n}{n} C_{t}^{H *}(i)$, and is produced with the following production technology:

$$
Y_{t}(i)=h_{t}(i)
$$

where $h_{t}(i)$ is the labor employed by the firm in period $t$. Market clearing in the labor market requires that the total demand for labor by firms is equal to the supply of labor from households, $\int_{0}^{n} h_{t}(i) d i=H_{t}$. The firm's marginal cost of production is simply equal to the wage rate.

In period $t$, the firm will be able to change its price(s) with probability $1-\xi_{p}$. If allowed 
to change their price in period $t$, the firm will set prices to maximize:

$\max _{P_{t}^{H d}(i), P_{t}^{H x}(i)} E_{t} \sum_{\tau=0}^{\infty} \beta^{\tau}\left(\xi_{p}\right)^{\tau} \Lambda_{t+\tau}\left[\left(P_{t}^{H d}(i)-W_{t+\tau}(i)\right) C_{t}^{H}(i)+\left(S_{t} P_{t}^{H x}(i)-W_{t+\tau}(i)\right) \frac{1-n}{n} C_{t}^{H *}(i)\right]$

where $\Lambda_{t}$ is the marginal utility of household consumption in period $t$.

The firm that can change prices will set their prices to:

$$
\begin{aligned}
\mathbf{P}_{t}^{H d}(i) & =\frac{E_{t} \sum_{\tau=0}^{\infty} \beta^{\tau}\left(\xi_{p}\right)^{\tau} \mu_{t+\tau} \Lambda_{t+\tau} W_{t+\tau}(i) C_{t+\tau}^{H}(i)}{E_{t} \sum_{\tau=0}^{\infty} \beta^{\tau}\left(\xi_{p}\right)^{\tau} \Lambda_{t+\tau} C_{t+\tau}^{H}(i)} \\
\mathbf{P}_{t}^{H x}(i) & =\frac{E_{t} \sum_{\tau=0}^{\infty} \beta^{\tau}\left(\xi_{p}\right)^{\tau} \mu_{t+\tau} \Lambda_{t+\tau} W_{t+\tau}(i) C_{t+\tau}^{H *}(i)}{E_{t} \sum_{\tau=0}^{\infty} \beta^{\tau}\left(\xi_{p}\right)^{\tau} S_{t+\tau} \Lambda_{t+\tau} C_{t+\tau}^{H *}(i)}
\end{aligned}
$$

where $\mu_{t}$ is the mark-up that the firm charges over expected future marginal cost. This mark-up is stochastic and follows an $\mathrm{AR}(1)$ process described in the next subsection.

Similarly, the price set by foreign firms for exports into the home economy is given by:

$$
\mathbf{P}_{t}^{F x}(j)=\frac{E_{t} \sum_{\tau=0}^{\infty} \beta^{\tau}\left(\xi_{p}\right)^{\tau} \mu_{t+\tau}^{*} \Lambda_{t+\tau}^{*} S_{t+\tau} W_{t+\tau}^{*}(j) C_{t+\tau}^{F}(j)}{E_{t} \sum_{\tau=0}^{\infty} \beta^{\tau}\left(\xi_{p}\right)^{\tau} \Lambda_{t+\tau}^{*} C_{t+\tau}^{F}(j)}
$$

Firms that can reset prices in period $t$ will all reset to the same level, so $\mathbf{P}_{t}^{H d}(i)=\mathbf{P}_{t}^{H d}$, $\mathbf{P}_{t}^{H x}(i)=\mathbf{P}_{t}^{H x}$, and $\mathbf{P}_{t}^{F x}(j)=\mathbf{P}_{t}^{F x}$. Substitute these optimal prices into the price indices $P_{t}^{H d}=\left(\int_{0}^{1}\left(P_{t}^{H d}(i)\right)^{1-\sigma} d i\right)^{\frac{1}{1-\sigma}}, P_{t}^{H x}=\left(\int_{0}^{1}\left(P_{t}^{H x}(i)\right)^{1-\sigma} d i\right)^{\frac{1}{1-\sigma}}$, and $P_{t}^{F x}=\left(\int_{0}^{1} P_{t}^{F x}(j)^{1-\sigma} d j\right)^{\frac{1}{1-\sigma}}$. Since a firm has a probability of $1-\xi_{p}$ of being able to change their price, then by the law of large numbers in any period $1-\xi_{p}$ percent of firms will reoptimize prices. Thus the price indices can be written as:

$$
\begin{aligned}
P_{t}^{H d} & =\left(\xi_{p}\left(P_{t-1}^{H d}\right)^{1-\sigma}+\left(1-\xi_{p}\right)\left(\mathbf{P}_{t}^{H d}\right)^{1-\sigma}\right)^{\frac{1}{1-\sigma}} \\
P_{t}^{H x} & =\left(\xi_{p}\left(P_{t-1}^{H x}\right)^{1-\sigma}+\left(1-\xi_{p}\right)\left(\mathbf{P}_{t}^{H x}\right)^{1-\sigma}\right)^{\frac{1}{1-\sigma}} \\
P_{t}^{F x} & =\left(\xi_{p}\left(P_{t-1}^{F x}\right)^{1-\sigma}+\left(1-\xi_{p}\right)\left(\mathbf{P}_{t}^{F x}\right)^{1-\sigma}\right)^{\frac{1}{1-\sigma}}
\end{aligned}
$$




\subsubsection{Log-linearized model equations}

The log-linearized equilibrium in this small open economy model can be expressed as solution to a system of equations with 12 variables: (1) domestic producer price inflation, $\pi_{t}^{H d},(2)$ export producer price inflation, $\pi_{t}^{H x}$, (3) import price inflation, $\pi_{t}^{H m}$, (4) the real price of domestic production, $\hat{p}_{t}^{H d}$, (5) the real price of exports, $\hat{p}_{t}^{H x}$, (6) the real price of imports, $\hat{p}_{t}^{F x}$, (7) consumer price inflation, $\pi_{t}^{C}$, (8) output, $\hat{Y}_{t},(9)$ consumption, $\hat{C}_{t},(10)$ the real exchange rate, $\hat{Q}_{t},(11)$ the change in the nominal exchange rate, $d \hat{S}_{t},(12)$ the markup shock, $\hat{\mu}_{t}$.

This model with 12 variables is described by 11 log-linearized equilibrium conditions. The last equation is left for monetary policy, and is discussed in the next subsection. The derivation of each of these log-linearized equations is presented in section 1 of the appendix. A "hat" over a variable represents log-deviation from the steady state value.

The firm pricing decisions, combined with the labor market equilibrium condition in (4) yield the following New Keynesian Phillips Curves:

$$
\begin{aligned}
\pi_{t}^{H d} & =\kappa\left(\hat{\mu}_{t}+\eta \hat{Y}_{t}+\rho \hat{C}_{t}-\hat{p}_{t}^{H d}\right)+\beta E_{t}\left(\pi_{t+1}^{H d}\right) \\
\pi_{t}^{H x} & =\kappa\left(\hat{\mu}_{t}+\eta \hat{Y}_{t}+\rho \hat{C}_{t}-\hat{Q}_{t}-\hat{p}_{t}^{H x}\right)+\beta E_{t}\left(\pi_{t+1}^{H x}\right) \\
\pi_{t}^{H m} & =\kappa\left(\hat{Q}_{t}-\hat{p}_{t}^{F x}\right)+\beta E_{t}\left(\pi_{t+1}^{H m}\right)
\end{aligned}
$$

where $\kappa=\frac{\left(1-\beta \xi_{p}\right)\left(1-\xi_{p}\right)}{\xi_{p}} .^{9}$

The expression for the domestic consumer price index in (3) yields the following expression for the real price of domestic production:

$$
\hat{p}_{t}^{H d}=-\frac{\lambda}{1-\lambda} \hat{p}_{t}^{F x}
$$

The definition of export price inflation leads to an equation describing the real price of exports:

$$
\hat{p}_{t}^{H x}-\hat{p}_{t-1}^{H x}=\pi_{t}^{H x}
$$

Similarly the definition of import price inflation leads to an equation describing the real price of imports: ${ }^{10}$

\footnotetext{
${ }^{9}$ Note that since the rest of the world is unaffected by events in the small open economy and the only shocks are domestic shocks, foreign aggregate variables are unchanged and only the exchange rate will enter the Phillips curve for import price inflation.

${ }^{10}$ In the model with producer currency pricing, the Phillips curve for $\pi_{t}^{H d}$ remains the same in (7), but the Phillips curve for $\pi_{t}^{H x}$ is replaced with $\pi_{t}^{H x}+d \hat{S}_{t}=\pi_{t}^{H d}$, and the Phillips curve for $\pi_{t}^{H m}$ is replaced with $\pi_{t}^{H m}=d \hat{S}_{t}$. The expression linking the change in the real price of exports with export price inflation in (11) is replaced with $\hat{p}_{t}^{H x}=\hat{p}_{t}^{H d}-\hat{Q}_{t}$. And the expression linking the change in the real price of imports to import price inflation in (12) is replaced with $\hat{p}_{t}^{F x}=\hat{Q}_{t}$.
} 


$$
\hat{p}_{t}^{F x}-\hat{p}_{t-1}^{F x}+\pi_{t}^{C}=\pi_{t}^{H m}
$$

Consumer price inflation is just a weighted average of domestic producer inflation and import inflation:

$$
\pi_{t}^{C}=(1-\lambda) \pi_{t}^{H d}+\lambda \pi_{t}^{H m}
$$

The market resource constraint can be written as:

$$
\hat{Y}_{t}=-\theta(1-\lambda) \hat{p}_{t}^{H d}-\theta \lambda \hat{p}_{t}^{H x}+(1-\lambda) \hat{C}_{t}
$$

Consumption and the real exchange rate are linked with the asset market equilibrium condition in (6):

$$
\hat{Q}_{t}=\rho \hat{C}_{t}
$$

Log-differences in the definition of the real exchange rate leads to the following expression for the change in the nominal exchange rate:

$$
\hat{Q}_{t}-\hat{Q}_{t-1}=d \hat{S}_{t}-\pi_{t}^{C}
$$

Finally, the model is driven by a mark-up shock $\hat{\mu}_{t}$ that follows an $\operatorname{AR}(1)$ process:

$$
\hat{\mu}_{t+1}=\rho_{\mu} \hat{\mu}_{t}+\varepsilon_{t+1}
$$

\subsection{Monetary Policy}

The central bank sets monetary policy in order to maximize the second-order approximation of the household's welfare in (1). Gali and Monacelli (2005) and De Paoli (2009) derive this loss function in the case of producer currency pricing. They show that the maximization of the second-order approximation of welfare is equivalent to the minimization of the quadratic loss function of the output gap, the inflation rate of home country produced goods, and the real exchange rate.

In the main text we will instead consider the model of local currency pricing. The quadratic form of the loss function under local currency pricing can be derived as the limiting case in the model in Fujiwara and Wang (2017). ${ }^{11}$ It is more complicated, owing to the fact that local currency pricing leads to violations of the law of one price and thus more distortions

\footnotetext{
${ }^{11}$ The quadratic loss is derived under commitment.
} 
in the economy (see e.g. Engel (2011)). The loss function takes the following functional form:

$$
L_{t}=\frac{1}{2} E_{t} \sum_{\tau=0}^{\infty} \beta^{\tau}\left(\begin{array}{c}
\Psi_{y}\left(\hat{Y}_{t+\tau}-\hat{Y}_{t+\tau}^{T, L C P}\right)^{2}+\Psi_{l o p}\left(\hat{p}_{t+\tau}^{H x}+\frac{1}{\rho \theta} \hat{Q}_{t+\tau}-\hat{p}_{t+\tau}^{H d}\right)^{2}+\Psi_{\pi d}\left(\pi_{t+\tau}^{H d}\right)^{2} \\
+\Psi_{\pi x}\left(\pi_{t+\tau}^{H x}\right)^{2}+\Psi_{\pi m}\left(\pi_{t+\tau}^{H m}\right)^{2}+\Psi_{q}\left(\hat{Q}_{t+\tau}\right)^{2}+\Psi_{p x}\left(\hat{p}_{t+\tau}^{H x}\right)^{2}+\Psi_{p f}\left(\hat{p}_{t+\tau}^{F x}\right)^{2} \\
+\Psi_{q f}\left(\hat{Q}_{t+\tau}-\hat{p}_{t+\tau}^{F x}\right)^{2}+\Psi_{q d}\left(\frac{1-\rho}{\rho} \hat{Q}_{t+\tau}+(1-\theta) \hat{p}_{t+\tau}^{H d}\right)^{2} \\
+\Psi_{d}\left(\hat{\mu}_{t+\tau}+(\eta+1) \hat{Y}_{t+\tau}+\theta \lambda\left(\hat{p}_{t+\tau}^{H x}+\frac{1}{\rho \theta} \hat{Q}_{t+\tau}-\hat{p}_{t+\tau}^{H d}\right)\right)^{2} \\
+\Psi_{x}\left(\hat{\mu}_{t+\tau}+\eta \hat{Y}_{t+\tau}+\rho \hat{C}_{t+\tau}-\hat{Q}_{t+\tau}-\hat{p}_{t+\tau}^{H x}\right)^{2}
\end{array}\right)
$$

The functional forms and numerical values of these 12 loss function coefficients are found in section 1 of the appendix.

Welfare maximizing policy will maximize social welfare (minimize the derived social loss function, $\left.L_{t}\right)$ subject to the log-linearized model equations (7)-(17).

\subsubsection{Boundary cases}

In the first set of results we will close the model under four boundary cases of monetary policy. The first case is where the central bank can perfectly commit, and thus it will minimize social loss $L_{t}$ by specifying the expected future path of domestic producer price inflation $\left\{\pi_{t+\tau}^{H d}\right\}_{\tau=0}^{\infty}$ conditional on a sequence of cost-push shocks. ${ }^{12}$

In addition to examining the outcomes under the ideal perfect commitment case, we will consider three monetary regimes where the central bank's optimization problem is replaced with a single mandate. The first is a purely external single mandate, a nominal exchange rate targeting regime, $d \hat{S}_{t}=0$. Next, we consider a purely domestic single mandate, a strict domestic producer price inflation targeting regime, $\pi_{t}^{H d}=0$. Finally we consider the strict consumer price inflation targeting regime $\pi_{t}^{C}=0$.

\subsubsection{Beyond boundary cases: Loose commitment and partial targeting}

After comparing nominal exchange rate targeting or inflation targeting to welfare maximizing policy under commitment we take a more granular approach. Instead of assuming that the central bank can perfectly commit, we assume that the central bank displays loose commitment, as in Schaumburg and Tambalotti (2007), Debortoli and Nunes (2010), De-

\footnotetext{
${ }^{12}$ Since this is a model with full information, the central bank can make policy by specifying the future path of any endogenous variable in the model, which variable is chosen as the policy instrument doesn't matter, so we simply pick $\pi^{H d}$. See Herrendorf $(1997,1999)$ for an example of a model where the central bank has private information that is not available to agents in the economy. In this case, the choice of a policy instrument is important.
} 
bortoli, Maih, and Nunes (2014), and Dennis (2014). Fujiwara, Kam, and Sunakawa (2016) show that outcomes of welfare maximizing policy with loose commitment are observationally equivalent to, or can be interpreted as, outcomes of optimal policy under sustainable plans, as in Chari and Kehoe (1990). With a certain exogenous probability policy makers may renege on their earlier commitments. This exogenous probability is known by all agents in the model. In any given period, the central bank will honor past commitments with probability $\gamma$ and it will renege on previous commitments and reoptimize with probability $1-\gamma$.

The central bank will seek to minimize the loss function in (18) subject to equations (7)(17) and the commitment probability $\gamma$. As $\gamma$ falls and the central bank lacks the ability to commit, welfare maximizing policy given $\gamma$ might not be the policy that maximizes ex-ante social welfare. To improve ex-ante social welfare and partially make up for the fact that the central bank displays limited commitment, the central bank may ex-ante choose to minimize a different loss function than the social loss function. This alternative loss function is known to all agents in the model and is a way to tie the central bank's hands and force them to adopt a policy that better mirrors the policy under perfect commitment. This alternative loss function doesn't actually make the central bank able to commit, and it still will renege with the exogenous probability $1-\gamma$. But by adopting a different objective function and thus a different set of trade-offs, the central bank that cannot perfectly commit can partially mitigate the time inconsistency problem and improve total social welfare given its limited ability to commit.

This is the idea behind the famous Rogoff (1985) conservative central banker. For this alternative loss function, we consider three possibilities. In the first, the policy maker places more weight on a domestic target, the domestic producer price inflation rate, in the second they place more weight on CPI inflation, and in the third the policy maker places more weight on an external target, the nominal exchange rate:

$$
\tilde{L}_{t}=L_{t}+E_{t} \sum_{\tau=0}^{\infty} \beta^{\tau} \psi_{i}(\gamma)(i)^{2} \text { for } i=\pi_{t+\tau}^{H d}, \pi_{t+\tau}^{C}, \text { or } d \hat{S}_{t+\tau}
$$

As the value of $\psi_{i}(\gamma)$ gets larger, monetary policy that minimizes the objective function $\tilde{L}_{t}$ approaches the case of domestic producer price inflation targeting, consumer price inflation targeting, or exchange rate targeting: $\pi_{t+\tau}^{H d}=0, \pi_{t+\tau}^{C}=0$, or $d \hat{S}_{t+\tau}=0$.

This modification of the social loss function, $\psi_{i}(\gamma)$, can be derived from numerical simulations of the model.

Commitment to what? If the central bank can perfectly commit, it specifies a future path of domestic producer price inflation $\left\{\pi_{t+\tau}^{H d}\right\}_{\tau=0}^{\infty}$ conditional on a sequence of shocks 
$\left\{\hat{\mu}_{t+\tau}\right\}_{\tau=0}^{\infty}$ that would minimize its objective function subject to the New Keynesian Phillips curves and market resource constraints. If the central bank can perfectly commit to this policy path and agents believe them, this will pin down the path of expected inflation. In the model with loose commitment, the central bank will specify a future path of inflation $\left\{\pi_{t+\tau}^{H d}\right\}_{\tau=0}^{\infty}$ conditional on a sequence of shocks which would minimize its objective function at time $t$, but in the next period with probability $1-\gamma$ it will reoptimize and specify a new future path of domestic producer price inflation $\left\{\pi_{t+1+\tau}^{H d}\right\}_{\tau=0}^{\infty}$ that would minimize its objective function at time $t+1$.

When forming expectations, agents would know that the reneging on past promises is a possibility. So when forming expectations given that the central bank displays loose commitment, expected inflation is not the same as the central bank's specified future path of inflation.

If given the chance to reoptimize, the central bank may break past promises and reoptimize because there are multiple terms in its objective function. In time $t$ it may specify a future path of inflation $\left\{\pi_{t+\tau}^{H d}\right\}_{\tau=0}^{\infty}$ that would minimize its objective function conditional on a sequence of shocks. If this announcement is believed by the agents in the model, this will fix inflation expectations. In time $t+1$ the central bank may take advantage of the fact that inflation expectations are fixed and deviate from their past promises in order to gain a temporary benefit in one of their other objectives, like output gap stabilization.

Thus as $\psi(\gamma) \rightarrow \infty$ in the modified central bank objective function in (19), it removes the multiple terms from the central bank's objective function. Without multiple terms in the objective function, even if the central bank could reoptimize, it would specify the same path. As $\psi_{\pi^{H}}(\gamma) \rightarrow \infty, \psi_{\pi^{C}}(\gamma) \rightarrow \infty$ or $\psi_{S}(\gamma) \rightarrow \infty$, the central bank's only concern is domestic producer price inflation stability, consumer price inflation stability or nominal exchange rate stability. Thus the central bank will announce a path of $\left\{\pi_{t+\tau}^{H d}=0\right\}_{\tau=0}^{\infty},\left\{\pi_{t+\tau}^{C}=0\right\}_{\tau=0}^{\infty}$ or $\left\{d \hat{S}_{t+\tau}=0\right\}_{\tau=0}^{\infty}$. If allowed to reoptimize in period $t+1$, optimal policy will still be $\left\{\pi_{t+1+\tau}^{H d}=0\right\}_{\tau=0}^{\infty},\left\{\pi_{t+1+\tau}^{C}=0\right\}_{\tau=0}^{\infty}$ or $\left\{d \hat{S}_{t+1+\tau}=0\right\}_{\tau=0}^{\infty}$.

Thus as $\psi_{\pi^{H}}(\gamma) \rightarrow \infty, \psi_{\pi^{C}}(\gamma) \rightarrow \infty$ or $\psi_{S}(\gamma) \rightarrow \infty$, the central bank adopts an inflation or exchange rate target. This target is actually built into the central bank's objective function, so in the model of loose commitment, when the central bank is allowed with probability $1-\gamma$ to reoptimize, they will reoptimize the objective function containing this $\psi(\gamma)$. The model of loose commitment does not consider the possibility that the central bank would renege on their commitment to an inflation or exchange rate target, which would be like saying that between period $t$ and $t+1, \psi(\gamma)$ falls to zero. In the model of loose commitment, the coefficients in the central bank's objective function are time invariant.

By assuming shocks are not permanent we assume that ultimately all variables revert to 
their steady state values, thus if the target is the steady state value, the inflation target or exchange rate target is sustainable. Furthermore, since the central bank's objective function, including the $\psi_{i}(\gamma)$ coefficient is known by all agents in the model, agents believe the central bank's commitment to any peg. And agents will not engage in the type of speculative attack that could lead to the breaking of an exchange rate regime and currency crisis.

At first glance, the assumption that even the central bank that cannot commit to a future course of policy given multiple terms in its objective function can still commit to something like a fixed exchange rate regime may seem like a stretch. After all, Obstfeld and Rogoff (1995) discuss the "mirage of fixed exchange rates" and note the high rate of failure of many exchange rate pegs. But Klein and Shambaugh (2008) note that while many exchange rate pegs fail, most fail quickly, possibly because the peg was set to an unreasonable level or it was brought down by speculative attacks from agents unsure of the central bank's objective. Klein and Shambaugh (2008) find that conditional on lasting two years, exchange rate pegs are very sustainable, and when a peg is broken following a shock, it is quickly reestablished.

\subsection{Calibration}

The calibrated values of the structural parameters in the model are presented in table 2 . The discount factor is set to 0.99 in this quarterly model. The Calvo price stickiness parameter $\xi_{p}$ is set such that firms adjust prices on average once every 4 quarters. The labor supply elasticity is set to 1 . The elasticity of substitution between goods from different firms is set to 10 , and the elasticity of substitution between home and foreign goods is set to 3 . Both values are common in the international macro literature. The intertemporal elasticity of substitution is set to 1 , indicating that agents have log-utility over consumption.

Numerical simulations of the model are calculated in response to home country markup shocks. We assume that these shocks follow an $\operatorname{AR}(1)$ process with an autoregressive parameter of $\rho_{\mu}=0.8$ and that these shocks have a standard deviation of $1 \%$.

In section 3 of the appendix we present extensive results showing the robustness of the model to different values of these parameters. Armenter and Bodenstein (2009) show that the persistence of shocks has a major effect on the benefits of a single mandate policy rule over purely discretionary monetary policy. When shock persistence is low, welfare maximizing policy, even under a central bank that cannot commit, yields a better outcome than a single mandate. So while in our benchmark results, we assume that the persistence of the cost-push shocks, $\rho_{\mu}=0.8$, in the appendix we test the robustness of the results to the assumption of very persistent cost-push shocks, $\rho_{\mu}=0.95$, or i.i.d. shocks, $\rho_{\mu}=0$. In section 3 of the appendix we also check the robustness of the results to changing the price stickiness 
parameter $\xi_{p}$, the elasticity of substitution between home and foreign goods $\theta$, and the labor supply elasticity $\eta$. In the appendix we also test the robustness of the results in the model with producer currency pricing.

\section{Model Results}

To examine the costs and benefits of adopting a simple rule like inflation targeting or nominal exchange rate targeting and discuss why trade openness is such an important factor in the decision to peg the exchange rate, we first calculate welfare costs under four assumptions about monetary policy. In one, monetary policy is set to maximize social welfare and the central bank can commit, and then we consider three single mandate regimes: the central bank follows a domestic producer price inflation targeting rule, the central bank follows a simple nominal exchange rate targeting rule, or the central bank follows a consumer price inflation targeting rule. We show that the costs and benefits of these simple rules depend on the economy's level of trade openness.

We then adopt a more granular approach. With the loose commitment framework, perfect commitment and perfect discretion are boundary cases where the commitment probability is either 1 or 0 . We can then calculate how a central bank with a given commitment probability might find it optimal to minimize an objective function that places greater weight on stabilizing the exchange rate or inflation.

\subsection{Impulse responses under different monetary regimes}

The responses of the home country output gap, inflation rate, and real exchange rate to a home country mark-up shock are shown in figure 1. The left-hand column of each figure presents the results from the model assuming an import share $\lambda=0.1$, and the righthand column assumes an import share $\lambda=0.5$. The solid blue line in each figure presents the results assuming welfare maximizing policy under commitment (recall that when the central bank can commit, welfare maximizing policy is optimal), the red dashed line assumes strict domestic producer price inflation targeting, the green line with stars assumes nominal exchange rate targeting, and the purple dotted line assumes strict consumer price inflation targeting.

Domestic producer price inflation targeting perfectly stabilizes domestic producer price inflation but the cost is higher output volatility as every shock has to be absorbed by fluctuations in output. Nominal exchange rate targeting allows some absorption through inflation, and thus following a shock, the result is higher inflation volatility but lower output volatility. 
The response of the output gap following a shock is lower than it would have been under welfare maximizing policy and the response of inflation is greater. CPI inflation targeting produces responses between those from domestic producer price inflation targeting and exchange rate targeting, and when the trade share is low, CPI inflation targeting produces results that are very similar to domestic producer price inflation targeting.

In the figure, as the trade share increases, the volatility of inflation under welfare maximizing policy increases. Thus the central bank of a more open economy is willing to allow more of the shock to be absorbed by inflation. Thus the responses under exchange rate targeting are closer to optimal policy when the import share is high, and the responses under domestic producer price inflation targeting are closer to the optimal when the import share is low.

\subsection{Social loss under different monetary regimes}

The volatility of the output gap, the domestic producer price inflation rate, the real exchange rate and the total social loss as a function of the import share $\lambda$ are presented in figure 2 . The solid blue line in each figure presents the results assuming welfare maximizing policy under commitment, the red dashed line assumes strict domestic producer price inflation targeting, the green line with stars assumes nominal exchange rate targeting, and the purple dotted line assumes strict consumer price inflation targeting.

This repeats the same trends that we see in the impulse response analysis. Output gap volatility is lowest under nominal exchange rate targeting and highest under domestic producer price inflation targeting, and inflation volatility is highest under nominal exchange rate targeting and zero under domestic producer price inflation targeting. As we see in the impulse response analysis, under welfare maximizing policy, inflation volatility is an increasing function of the import share, implying that the central bank of a more open economy is willing to tolerate more inflation volatility.

The lower-right-hand plot presents the difference between social welfare loss under one of the three simple rules and social welfare loss under welfare maximizing policy. Welfare maximizing policy under perfect commitment of course results in a lower social welfare loss than any of the simple rule regimes. For low levels of trade openness, domestic producer price inflation targeting results in a lower social loss than nominal exchange rate targeting, but as the trade share increases, this ordering reverses. At some point, under this calibration where $\lambda>0.2$, the ordering changes and nominal exchange rate targeting results in a lower social welfare loss than domestic producer price inflation targeting, implying that as the trade share increases, the relative benefits of nominal exchange rate targeting increase. 
The consumer price inflation targeting regime and the domestic producer price inflation targeting regime are equivalent when $\lambda=0$. As $\lambda$ increases, consumer price inflation targeting results in a lower social welfare loss than domestic producer price inflation targeting. CPI inflation targeting outperforms exchange rate targeting, but around the point where $\lambda>0.35$, nominal exchange rate targeting results in a lower welfare loss than CPI inflation targeting.

\subsection{The optimal weight on exchange rate stability, $\psi$}

Naturally, welfare maximizing policy under commitment is optimal, and thus it is better than (or at least as good as) any other monetary regime. To understand why economies may choose to adopt a single mandate, and specifically why a highly open economy may adopt nominal exchange rate targeting, we relax the assumption that the central bank can commit.

For this we turn to the "loose commitment" framework of Schaumburg and Tambalotti (2007) and Debortoli and Nunes (2010). In any period, the central bank will honor past commitments with probability $\gamma$ and it will renege on previous commitments and reoptimize with probability $1-\gamma$. This exogenous probability is known by all agents in the model. Commitment from the previous section is a special case where $\gamma=1$. Purely discretionary policy would be the special case where $\gamma=0$.

The change in welfare loss as the central bank's commitment probability $\gamma$ changes is plotted in figure 3. Each figure presents the difference between welfare loss for a certain value of the commitment probability $\gamma$ and welfare loss under welfare maximizing policy under commitment. Since welfare maximizing policy under commitment $(\gamma=1)$ always yields a lower social loss than policy when $\gamma<1$, the difference is always positive. The different plots in the figure assume different values of the steady state import share $\lambda$. The figure shows that welfare loss rises quickly as $\gamma$ decreases.

One possible solution for the central bank to overcome the problem of loose commitment is to maximize an objective function that is different than the social welfare function. Three possible candidates are given in (19). Under one possible candidate, the central bank places more weight on domestic producer price inflation $\psi_{\pi^{H}}(\gamma)$, under the second the central bank places weight on consumer price inflation $\psi_{\pi^{C}}(\gamma)$, and under the third the central bank places weight on nominal exchange rate stability $\psi_{S}(\gamma)$.

The values of these functions $\psi_{i}(\gamma)$ that minimize the social loss for a given value of $\gamma$ are solved for numerically. The numerically derived functions $\psi_{\pi^{H}}(\gamma), \psi_{\pi^{C}}(\gamma)$, or $\psi_{S}(\gamma)$ that minimize total social loss are presented in figure 4. In each graph, four lines are plotted, corresponding to different values of the steady state import share, $\lambda$ : the red dashed line is 
calculated for $\lambda=0.5$, the green line with stars is calculated for $\lambda=0.38$, the blue solid line is calculated for $\lambda=0.25$, and the purple dotted line is calculated for $\lambda=0.12$.

As $\psi(\gamma)$ gets larger, monetary policy approaches one of the single mandates discussed earlier, and for practical purposes in this numerical simulation, when $\psi(\gamma)$ approaches 500, the weight on the added inflation or exchange rate term in the loss function becomes so large that for all practical purposes, monetary policy converges to a single mandate rule (the numerical values of each of the loss function coefficients are presented in section 1 of the appendix, the value $\psi(\gamma)=500$ is large enough relative to these loss function coefficients to drive the objective function towards a single mandate). When $\gamma$ is close to 1 , indicating near perfect commitment, the value of $\psi(\gamma)$ is 0 , and as $\gamma$ falls the optimal weight increases, so $\frac{d \psi(\gamma)}{d \gamma}<0$.

But it is interesting to note the speed at which the central bank finds optimal to adopt one of these mandates as the commitment probability falls, and how this varies depending on the level of trade openness.

The top graph in the figures shows the results for the case of the domestic producer price inflation target. When the trade share is high, the central bank never finds it optimal to adopt a domestic producer price inflation target as a single mandate, even as $\gamma$ approaches zero. When the trade share is low the central bank will find it optimal to target domestic producer price inflation for low levels of the commitment probability. When $\lambda=0.12$ the central bank will adopt a domestic producer price inflation target when the commitment probability falls below $40 \%$. When $\lambda=0.25$ it will adopt a domestic producer price inflation target when the commitment probability is around $10 \%{ }^{13}$

The middle graph in the figures shows the results for the case of the consumer price inflation target. Placing weight on consumer price inflation outperforms the model of placing extra weight on domestic producer price inflation, and the central bank will adopt a strict consumer price inflation target when the commitment probability falls below $50 \%$. The trade share has a slight effect on the level of the commitment probability at which the central bank adopts a CPI inflation target, and the central bank will adopt a CPI inflation target at a higher level of the commitment probability when the trade share is high. But the difference is small. When $\lambda=0.5$ the central bank will adopt a CPI inflation target when the commitment probability falls below $55 \%$, and when $\lambda=0.25$, this probability cutoff is $45 \%$.

\footnotetext{
${ }^{13}$ In the appendix we present the results from the model assuming producer currency pricing. In this model, the central bank will find it optimal to adopt a domestic producer price inflation target at low levels of the commitment probability. This mirrors the result in Devereux, Lane, and Xu (2006), which find that under local currency pricing, domestic inflation targeting fares rather poorly, but under producer currency pricing, domestic inflation targeting can be an optimal policy.
} 
The bottom graph in the figure presents the optimal weight on exchange rate stability in the central bank's modified objective function. When the trade share is high, the central bank will adopt an exchange rate target at a much higher level of the commitment probability. When the import share $\lambda=0.5$, the central bank switches from welfare maximizing policy to a nominal exchange rate targeting single mandate when the commitment probability falls below $70 \%$, but when $\lambda=0.38$ the exchange rate target does not become optimal until the commitment probability falls below $50 \%$, and when $\lambda=0.25$, this probability cutoff is just over $15 \%$.

For the small economy that is nearly closed to trade the function $\psi_{S}(\gamma)$ remains equal to 0 at all levels of $\gamma$, indicating that even a central bank that lacks any ability to commit, $\gamma=0$, will still find it optimal to practice discretionary monetary policy instead of nominal exchange rate targeting. In other words, $\frac{d \psi_{S}(\gamma)}{d \gamma} \approx 0$ when $\lambda$ is close to zero.

The slope $\frac{d \psi_{S}(\gamma)}{d \gamma}$ depends on the level of trade openness, the slope is steeper (more negative) for a very open economy than for a relatively closed economy, so the numerically derived function $\psi_{S}(\gamma)$ can more accurately be written as $\psi_{S}(\gamma ; \lambda)$, where $\frac{d^{2} \psi_{S}(\gamma ; \lambda)}{d \gamma d \lambda}<0$.

Returning now to the welfare loss graphs in figure 3. As discussed earlier, the blue solid line in each graph represents the welfare loss under welfare maximizing policy. The red dashed line represents the social welfare loss when the central bank is instead minimizing the alternative objective function that places weight on domestic producer price inflation stability, the purple dotted line plots loss when the alternative objective function contains a role for consumer price inflation, and the green dash-dot line plots loss when the central bank is minimizing the alternative objective function that places weight on nominal exchange rate stability.

The lines are indistinguishable at high levels of $\gamma$, but at lower levels of $\gamma$ the lines representing welfare costs when the central bank places more weight on inflation or nominal exchange rate stability diverge. The welfare costs to adding weight to domestic producer price inflation are always higher than the costs to adding weight to consumer price inflation. For low levels of $\lambda$, adding weight to exchange rate stability results in a greater social loss than the two inflation stability regimes. But as $\lambda$ increases the relative performance of an objective function that favors exchange rate stability improves.

\subsubsection{Parallels with the empirical results}

The results from the model show that as the probability of commitment falls, the central bank will find it optimal to modify their objective function and place more weight on exchange rate stability. And in the model, this tendency to substitute exchange rate stabilization for a low commitment probability is especially pronounced for a highly open economy. 
If we assume that the commitment probability $\gamma$ in the model of loose commitment is related to the credibility index in the empirical results, and that the weight on the exchange rate in the central bank's modified loss function is inversely related to the exchange rate regime index from the empirical results, then the results in columns 1 and 3 of table 1 would imply that $\frac{d \psi_{S}(\gamma)}{d \gamma}<0$, exactly as is predicted by the model with loose commitment. ${ }^{14}$

Furthermore, if we consider the steady state import share $\lambda$ in the model to be positively related to the empirical trade share, then the results in columns 2 and 4 of the table would imply that $\frac{d^{2} \psi_{S}(\gamma ; \lambda)}{d \gamma d \lambda}<0$, and for a country that is relatively closed to trade, where the trade share variable is close to zero, $\frac{d \psi_{S}(\gamma)}{d \gamma} \approx 0$, both of these results are predicted by the model with loose commitment. ${ }^{15}$

\section{Summary and Conclusion}

Why do countries adopt an inflation target or a fixed exchange rate? One answer is that the country lacks the ability to commit to a future course of monetary policy actions. This time-inconsistency problem can be mitigated when the central bank adopts a single mandate like a mandate for inflation stabilization or nominal exchange rate stabilization. The costs and benefits of these monetary regimes depend on a country's level of trade openness.

The results in this paper show that in response to shocks that force the central bank to make a trade-off between inflation and output growth, nominal exchange rate targeting is more "dovish" than optimal policy, and a strict mandate for domestic producer price inflation stabilization is more "hawkish" than optimal. That is, a nominal exchange rate targeting regime would result in greater inflation variability relative to output variability than would occur if the central bank were practicing optimal policy under commitment, and a strict domestic producer price inflation target would lead to no inflation variability, but at the expense of high output variability. But for exchange rate targeting, the extent of this dovishness is a function of the import share, as trade openness increases, monetary policy under nominal exchange rate targeting gets closer to optimal monetary policy, and the

\footnotetext{
${ }^{14}$ Recall that as the exchange rate index increases, the currency moves towards floating on the fix-float scale, but as $\psi_{S}$ increases, the central bank places more weight on exchange rate stability in their objective functions.

${ }^{15}$ It should be emphasized that the link between the empirical results and those in the model are qualitative, not quantitative. In the empirical section we used central bank independence as a proxy for the commitment probability $\gamma$ in the model and an index of exchange rate flexibility as a proxy for the weight on the exchange rate $\psi_{S}$. We are not claiming to know the quantitative relationship between the credibility index and the commitment probability or between the index of exchange rate flexibility and the weight on exchange rate stability in the central bank's loss function. So we cannot make a quantitative claim about the empirical relationship between the credibility index and the exchange rate flexibility index, and how it relates to the quantitative relationship between the probability of commitment and the weight on exchange rate stability.
} 
exchange rate targeting rule delivers higher social welfare than an inflation targeting rule.

Empirically, this is in fact the case. In a panel data regression, as central bank independence (a proxy for credibility) falls, a central bank is more likely to adopt an exchange rate peg. Crucially, this link between credibility and exchange rate flexibility is a function of trade openness, and this empirical link is strong for highly open economies but weak for relatively closed economies. These empirical findings are perfectly matched in a model of loose commitment, as the central bank's ability to commit falls, the highly open economy will quickly find it optimal to abandon an independent monetary policy and tie their hands by pegging the nominal exchange rate. For less open economies, this willingness to adopt a fixed exchange rate is much weaker. For a low enough level of trade openness, a purely discretionary monetary policy is still superior to an exchange rate peg. 


\section{References}

Alesina, A., And L. H. Summers (1993): "Central bank independence and macroeconomic performance: some comparative evidence," Journal of Money, Credit and Banking, pp. $151-162$.

Armenter, R., and M. R. Bodenstein (2009): "Of Nutters and Doves," The BE Journal of Macroeconomics, 9(1), 1-22.

Ball, L. M., and N. Sheridan (2005): "Does Inflation Targeting Make a Difference?," in The Inflation-Targeting Debate, ed. by B. S. Bernanke, and M. Woodford, pp. 249-282. University of Chicago Press.

Barro, R. J., and D. B. Gordon (1983): "A Positive Theory of Monetary Policy in a Natural Rate Model," Journal of Political Economy, 91(4), 589-610.

Beechey, M. J., B. K. Johannsen, And A. T. Levin (2011): "Are Long-Run Inflation Expectations More Firmly Anchored in the Euro-Area Than in the United States?," American Economic Journal: Macroeconomics, 3, 104-129.

Benati, L. (2008): "Investigating Inflation Persistence Across Monetary Regimes," Quarterly Journal of Economics, 123(3), 1005-1060.

Bernanke, B. S., T. Laubach, and F. S. Mishkin (2001): Inflation targeting: lessons from the international experience. Princeton University Press, Princeton, NJ.

Blinder, A. S. (2000): "Central bank credibility: why do we care? How do we build it?," American Economic Review, 90, 1421-1431.

Bordo, M. D. (2003): "Exchange rate regime choice in historical perspective," NBER Working Paper no. 9654.

Bordo, M. D., And F. E. Kydland (1995): "The gold standard as a rule: An essay in exploration," Explorations in Economic History, 32(4), 423-464.

Brito, R. D., And B. Bystedt (2010): "Inflation Targeting in Emerging Economies, Panel Evidence," Journal of Development Economics, 91, 198-210.

Calderón, C., and K. Schmidt-Hebbel (2003): "Macroeconomic policies and performance in Latin America," Journal of International Money and Finance, 22(7), 895-923.

Calvo, G. A., and C. M. Reinhart (2002): "Fear of floating," Quarterly Journal of Economics, 117(2), 379-408.

Campa, J. M., and L. S. Goldberg (2005): "Exchange Rate Pass Through into Import Prices," Review of Economics and Statistics, 87(4), 679-690.

Chari, V. V., And P. J. Kehoe (1990): "Sustainable plans," Journal of political economy, 98(4), 783-802. 
Crowe, C. (2010): "Testing the Transparency Benefits of Inflation Targeting: Evidence from Private Sector Forecasts," Journal of Monetary Economics, 57, 226-232.

Cukierman, A. (1992): Central bank strategy, credibility, and independence: Theory and evidence. MIT press, Cambridge, MA.

DAVIS, S. (2014): "Inflation targeting and the anchoring of inflation expectations: Evidence from Consensus forecasts," Federal Reserve Bank of Dallas, Globalization and Monetary Policy Institute Working Paper no. 174.

De Paoli, B. (2009): "Monetary policy and welfare in a small open economy," Journal of International Economics, 77(1), 11-22.

Debortoli, D., J. Maih, and R. Nunes (2014): "Loose commitment in medium-scale macroeconomic models: Theory and applications," Macroeconomic Dynamics, 18(01), $175-198$.

Debortoli, D., and R. Nunes (2010): "Fiscal policy under loose commitment," Journal of Economic Theory, 145(3), 1005-1032.

Dennis, R. (2014): "Imperfect credibility and robust monetary policy," Journal of Economic Dynamics and Control, 44, 218-234.

Devereux, M. B., And C. Engel (2003): "Monetary policy in the open economy revisited: Price setting and exchange-rate flexibility," The Review of Economic Studies, 70(4), 765783.

Devereux, M. B., P. R. Lane, and J. Xu (2006): "Exchange Rates and Monetary Policy in Emerging Market Economies," Economic Journal, 116(511), 478-506.

Dincer, N. N., And B. Eichengreen (2013): "Central Bank Transparency and Independence: Updates and New Measures," Bank of Korea Working Paper no. 2013-21.

Engel, C. (2011): "Currency Misalignments and Optimal Monetary Policy: A Reexamination," The American Economic Review, 101(6), 2796-2822.

Fleming, J. M. (1962): "Domestic Financial Policies Under Fixed and Under Floating Exchange Rates," Staff Papers, International Monetary Fund, 9, 369-379.

Fujiwara, I., T. Kam, and T. Sunakawa (2016): "A note on imperfect credibility," CAMA Working Paper 37/2016.

Fujiwara, I., And J. Wang (2017): "Optimal Monetary Policy in Open Economies Revisited," Journal of International Economics, 108, 300-314.

Gali, J., and T. Monacelli (2005): "Monetary policy and exchange rate volatility in a small open economy," The Review of Economic Studies, 72(3), 707-734. 
Ghosh, A. (2014): "A comparison of exchange rate regime choice in emerging markets with advanced and low income nations for 1999-2011," International Review of Economics 8 Finance, 33, 358-370.

Ghosh, A. R., J. D. Ostry, and M. Chamon (2016): "Two targets, two instruments: Monetary and exchange rate policies in emerging market economies," Journal of International Money and Finance, 60, 172-196.

Giavazzi, F., And A. Giovannini (1989): Limiting exchange rate flexibility: The European monetary system. Mit Press, Cambridge, MA.

Giavazzi, F., And M. Pagano (1988): "The advantage of tying one's hands: EMS discipline and central bank credibility," European Economic Review, 32(5), 1055-1075.

Gonçalves, C. E. S., And J. M. Salles (2008): "Inflation Targeting in Emerging Economies: What do the data say?," Journal of Development Economics, 85, 312-318.

Gürkaynak, R. S., A. T. Levin, and E. T. Swanson (2006): "Does Inflation Targeting Anchor Long-Run Inflation Expectations? Evidence from Long-Term Bond Yields in the U.S., U.K., and Sweden," Discussion Paper Federal Reserve Bank of San Francisco Working Paper no. 2006-09.

Gürkaynak, R. S., A. N. Marder, A. T. Levin, and E. T. Swanson (2007): "Inflation Targeting and the Anchoring of Inflation Expectations in the Western Hemisphere," FRBSF Economic Review, pp. 25-47.

HakurA, D. (2005): “Are emerging market countries learning to float?," IMF Working Paper No. 05/98.

Herrendorf, B. (1997): "Importing credibility through exchange rate pegging," The Economic Journal, 107(442), 687-694.

(1999): "Transparency, reputation, and credibility under floating and pegged exchange rates," Journal of International Economics, 49(1), 31-50.

Husain, A. M., A. Mody, And K. S. Rogoff (2005): "Exchange rate regime durability and performance in developing versus advanced economies," Journal of Monetary Economics, 52(1), 35-64.

Ilzetzki, E., C. M. Reinhart, and K. S. Rogoff (2008): "Exchange rate arrangements entering the 21st century: Which anchor will hold?," mimeo.

Kamenik, O., and M. Kumhof (2014): "Trade Openness and Exchange Rate Regimes," Journal of Money, Credit and Banking, 46(8), 1657-1686.

Klein, M. W., and J. C. Shambaugh (2008): "The dynamics of exchange rate regimes: Fixes, floats, and flips," Journal of International Economics, 75(1), 70-92.

Kydland, F. E., and E. C. Prescott (1977): "Rules rather than discretion: The inconsistency of optimal plans," The Journal of Political Economy, pp. 473-491. 
Levy Yeyati, E., F. Sturzenegger, and I. Reggio (2010): "On the endogeneity of exchange rate regimes," European Economic Review, 54(5), 659-677.

Lin, S., And H. Ye (2007): "Does Inflation Targeting Really Make a Difference? Evaluating the Treatment Effect of Inflation Targeting in Seven Industrial Economies," Journal of Monetary Economics, 54, 2521-2533.

(2009): "Does Inflation Targeting Make a Difference in Developing Countries?," Journal of Development Economics, 89, 118-123.

Menrotra, A., and J. Yetman (2014): "Decaying expctations: what inflation forecasts tell us about the anchoring of inflation expctations," BIS Working Paper no. 464.

Mishkin, F. S., And G. A. Calvo (2003): "The Mirage of Exchange Rate Regimes for Emerging Market Countries," Journal of economic perspectives, 17(4), 99-118.

Mishikin, F. S., and K. Schmidt-Hebbel (2007): "Does Inflation Targeting Make a Difference?," in Monetary Policy under Inflation Targeting, ed. by F. S. Mishkin, K. SchmidtHebbel, and N. Loayza, pp. 291-372. Central Bank of chile.

Mundell, R. A. (1963): "Capital Mobility and Stabilization Policy under Fixed and Flexible Exchange Rates," Canadian Journal of Economics and Political Science, 29(4), 475485.

Obstfeld, M., and K. Rogoff (1995): "The Mirage of Fixed Exchange Rates," Journal of Economic Perspectives, 9(4), 73-96.

(1996): Foundations of International Macroeconomics. The MIT Press, Cambridge, Massachusetts.

Rogoff, K. (1985): "The optimal degree of commitment to an intermediate monetary target," The Quarterly Journal of Economics, pp. 1169-1189.

Romer, D. (1993): "Openness and inflation: theory and evidence," The Quarterly Journal of Economics, 108(4), 869-903.

Schaumburg, E., and A. Tambalotti (2007): "An investigation of the gains from commitment in monetary policy," Journal of Monetary Economics, 54(2), 302-324.

Walsh, C. E. (2007): "Transparency, Flexibility, and Inflation Targeting," in Monetary Policy under Inflation Targeting, ed. by F. S. Mishkin, K. Schmidt-Hebbel, and N. Loayza, pp. 227-263. Central Bank of chile.

Woodford, M. (2003): Interest and Prices: Foundations of a Theory of Monetary Policy. Princeton University Press, Princeton, New Jersey. 


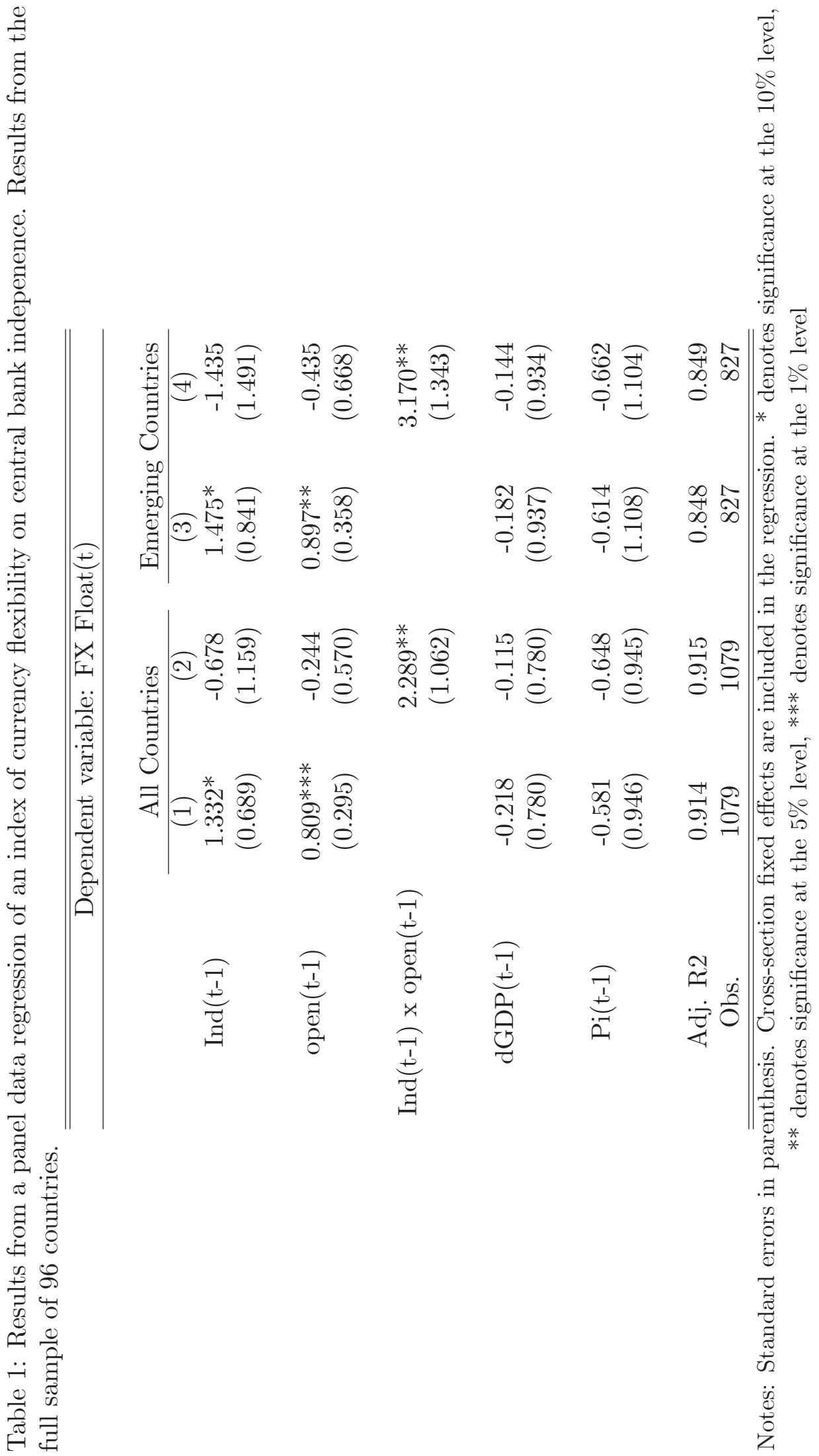


Table 2: Model parameter values.

\begin{tabular}{lcl}
\hline \hline Parameters & Values & Explanation \\
\hline$\xi_{p}$ & 0.75 & Percent of firms that cannot change price in a given period \\
$\beta$ & 0.99 & Subjective discount factor \\
$\eta$ & 1 & Inverse of the Frisch elasticity \\
$\sigma$ & 10 & Elasticity of substitution among differentiated goods from same country \\
$\theta$ & 3 & Elasticity of substitution between home and foreign goods \\
$\rho$ & 1 & Intertemporal elasticity of substitution \\
$\kappa$ & 0.08 & $\frac{\left(1-\beta \xi_{p}\right)\left(1-\xi_{p}\right)}{\xi_{p}}$ \\
\hline \hline
\end{tabular}


Figure 1: Responses to a cost-push shock.
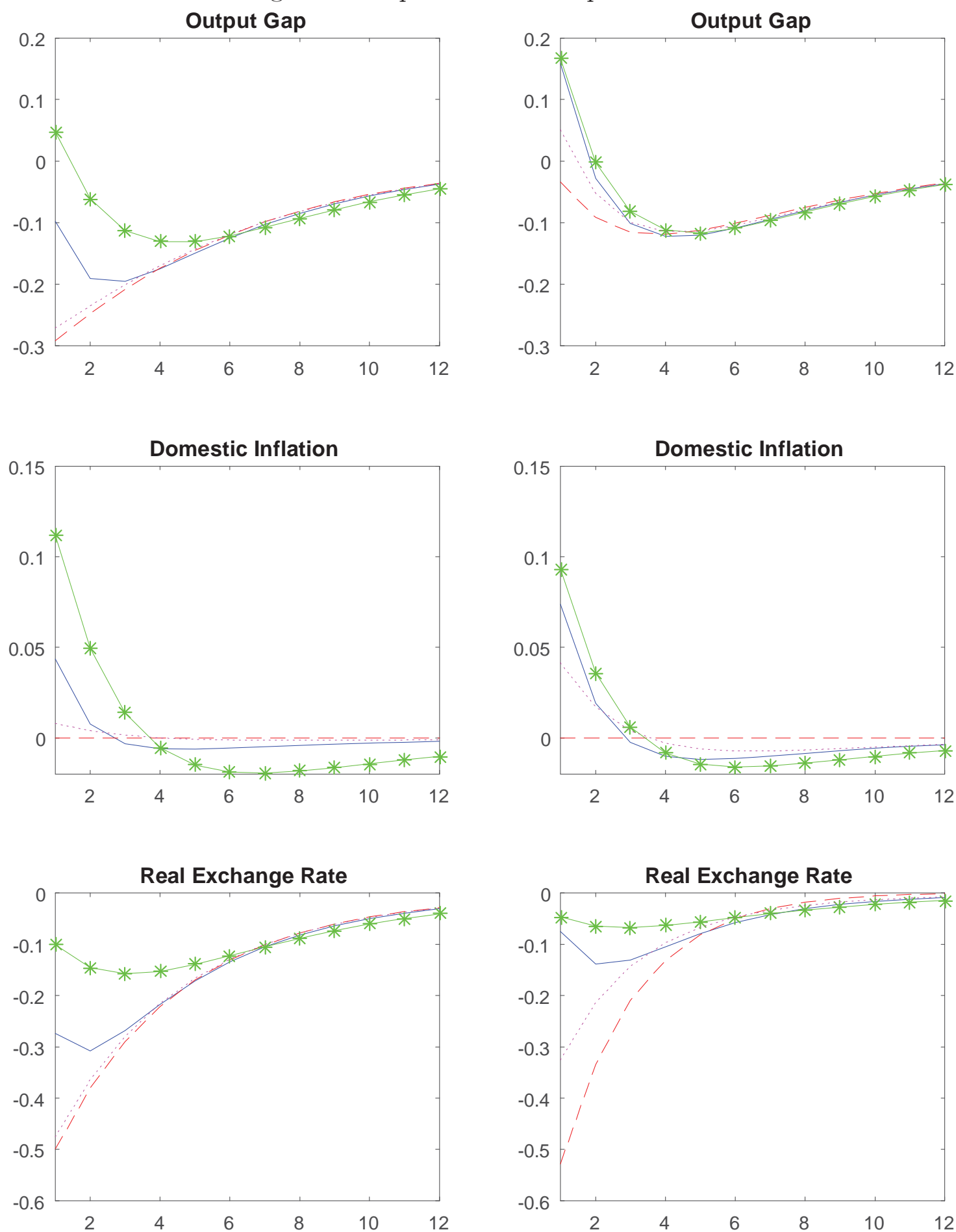

The left hand column is for the economy with a low import share and the right hand column is for a high import share. Blue solid line: Commitment, Purple dotted line: CPI inflation targeting , Red dashed line: Domestic producer price inflation targeting, Green starred line: Exchange rate targeting 
Figure 2: Volatilities of the output gap, inflation, and the real exchange rate as a function of the import share
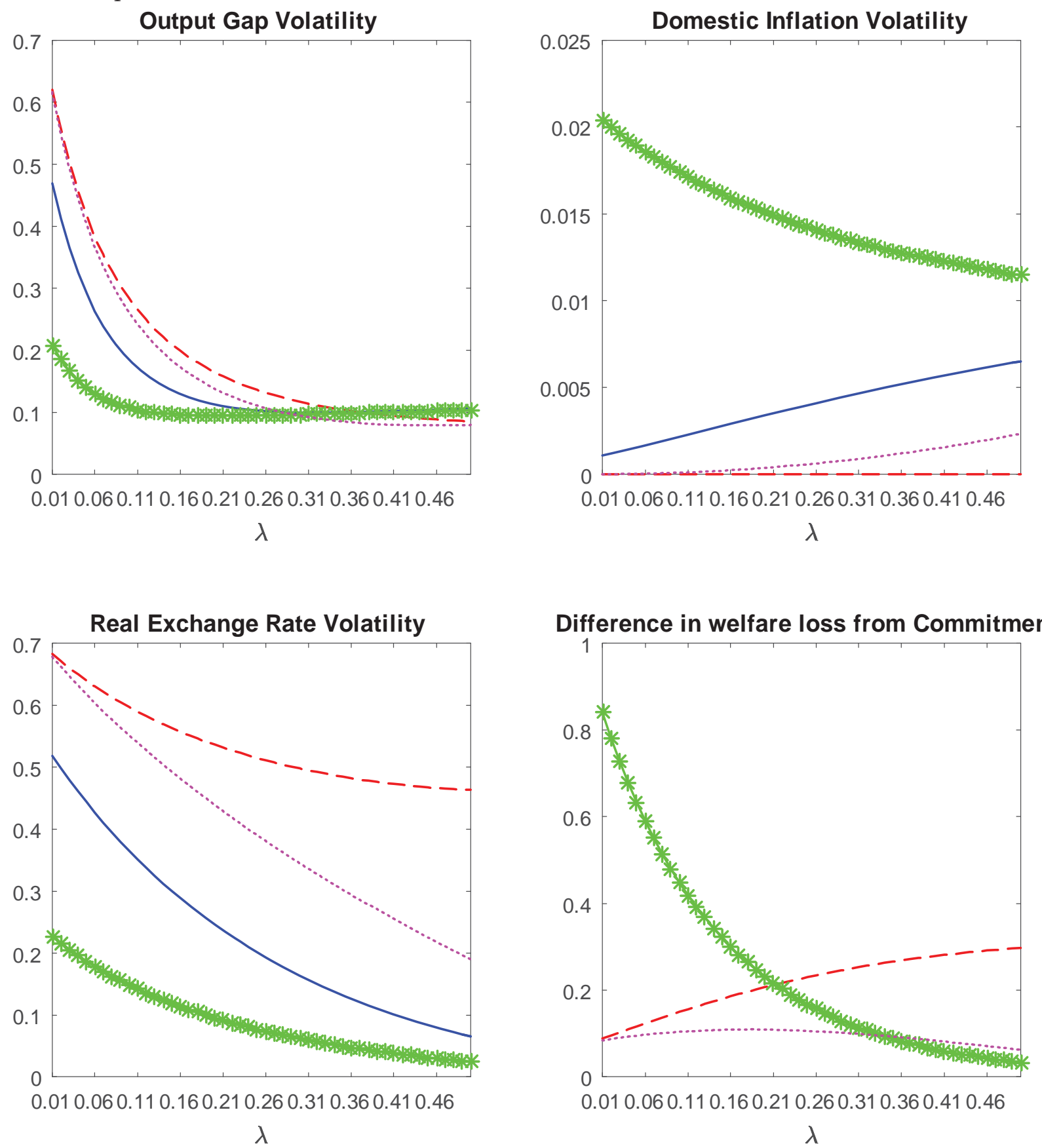

Blue solid line: Welfare maximizing policy under commitment, Red dashed line: Domestic inflation targeting, Green starred line: Exchange rate targeting, Purple dotted line: CPI inflation targeting. 
Figure 3: Social welfare loss as a function of the commitment probability $\gamma$, under 4 levels of trade openness.
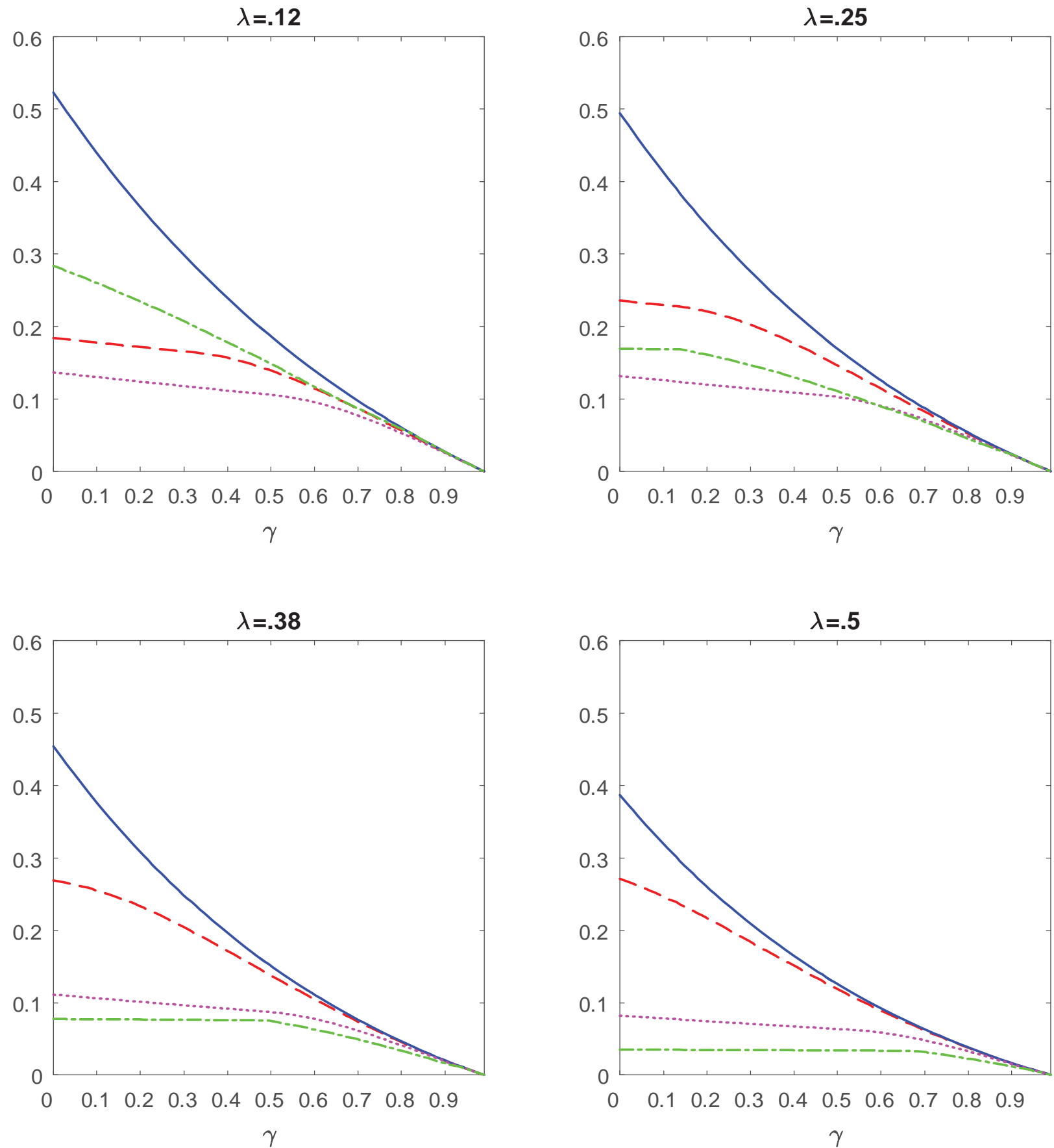

Blue solid line: Welfare maximizing policy, Red dashed line: Extra weight on domestic producer price inflation, Green dash-dot line: Weight on exchange rate stability, Purple dotted line: Weight on CPI inflation. 
Figure 4: Optimal weight on inflation or nominal exchange rate stability in the central bank's loss function as a function of the commitment probability.

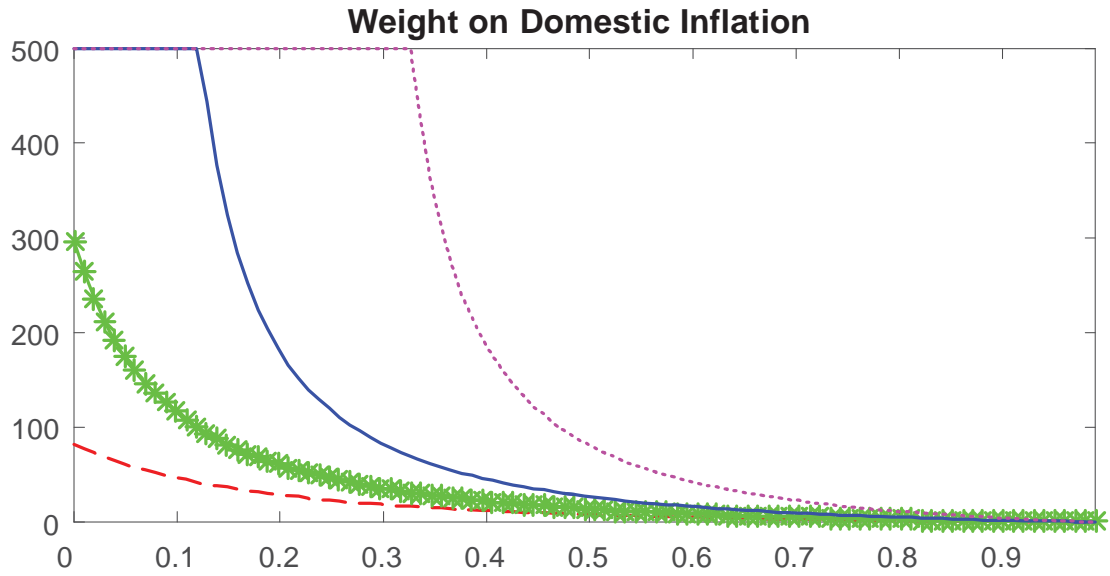

Weight on Consumer Inflation

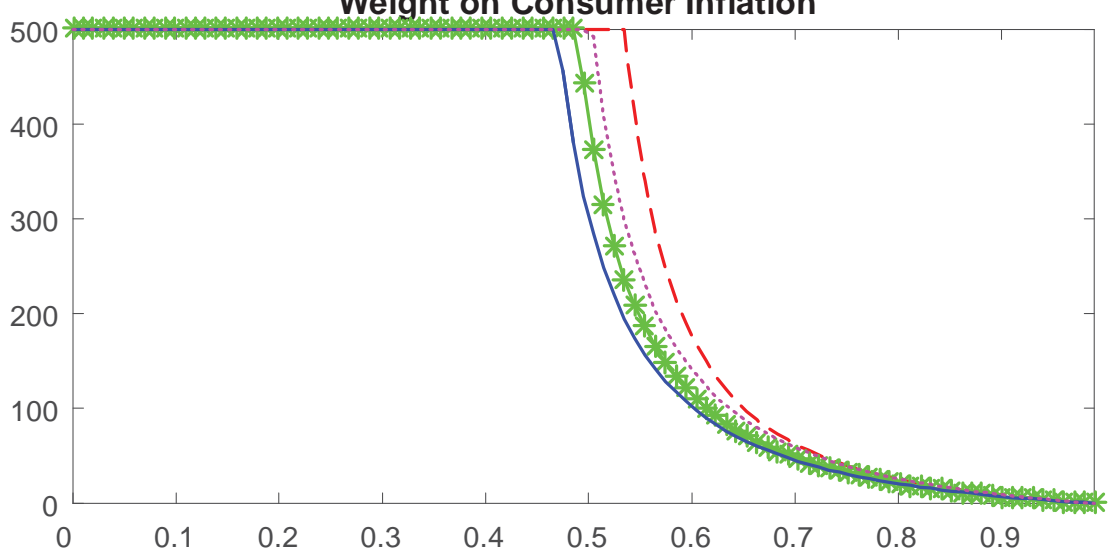

Weight on Exchange Rate

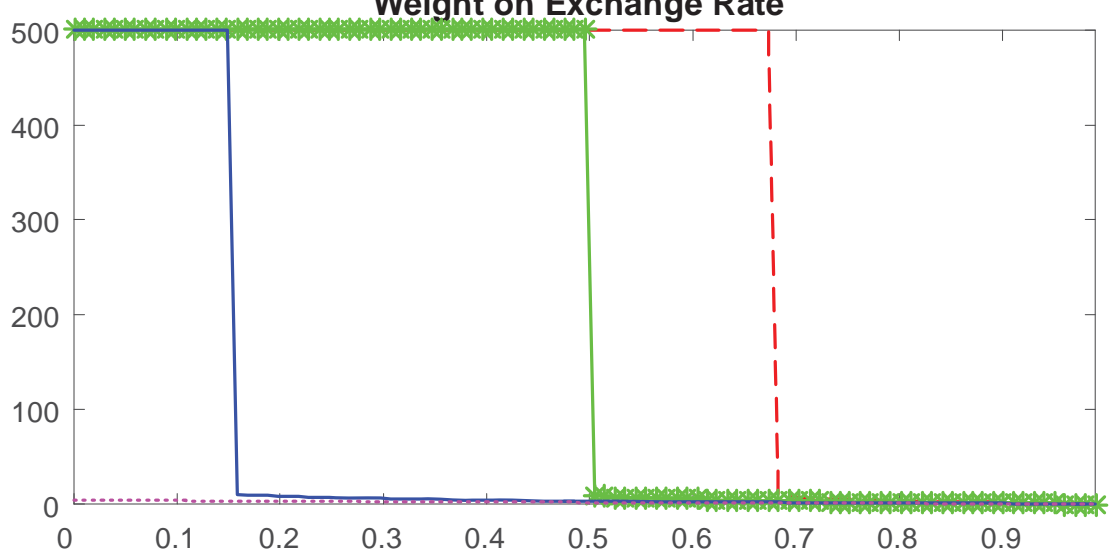

Red dashed line is for import share, $\lambda=0.5$, green line with stars is for $\lambda=0.38$, blue solid line is for $\lambda=0.25$, and purple dotted line is for $\lambda=0.12$. 